\begin{tabular}{|l|l|l|l|l|l|l|}
\hline InterteXto & Uberaba & UFTM & $\begin{array}{l}\text { v. 3 } \\
\text { n. 2 }\end{array}$ & p. 82-106 & 2010 - jul. / dez. & ISSN 1981-0601 \\
\end{tabular}

\title{
A PERSONAGEM MEDEA NO TEATRO DE AGOSTINHO OLAVO: UM ESTUDO DE FEITIÇARIA AFRICANA
}

\section{THE CHARACTER MEDEA IN AGOSTINHO OLAVOS' THEATER: AN STUDY OF AFRICAN WITCHERY}

\section{Wilson Filho Ribeiro de Almeida ${ }^{1}$}

\begin{abstract}
Resumo: Este artigo tem o objetivo de observar as transfigurações da personagem Medeia na literatura brasileira, pautando-se, em especial, no tema da feitiçaria. Este estudo centra-se na peça teatral Além do rio (Medea), de Agostinho Olavo, escrita em 1957, mas publicada apenas em 1961, no livro Dramas para negros e prólogo para brancos - antologia do teatro brasileiro. Nessa peça, Olavo ambienta o mito grego no Brasil colonial, caracterizando Medeia com uma rainha africana.
\end{abstract}

Palavras-chave: Feitiçaria; Teatro; Agostinho Olavo; Medea.

Abstract: This article has the objective of observe the character Medea's transfigurations in the brazilian literature, directing, especially, to the witchery theme. This study focuses on the Agostinho Olavo's play Além do rio (Medea), written in 1957, but only plubished in 1961, in the book Dramas para negros e prólogo para brancos antologia do teatro brasileiro. In this play, Olavo adapt the greek myth to the colonial Brazil, characterizing Medea as an african queen.

Key-words: Witchery; Theater; Agostinho Olavo; Medea.

Segundo Jean-Pierre Vernant, o mito é um relato originado da transmissão e da memória de uma sociedade, apresentando-se, deste modo, como uma história vinda de épocas passadas. Não sendo resultado da criação individual, "a narrativa mítica diferencia-se do texto poético pelo fato de comportar variantes, versões distintas, ou seja, permite ao narrador acrescentar e modificar a narrativa de acordo com o público ao qual se destinava." (VERNANT apud CANDIDO, [20--], pp. 1-2).

A história de Medeia constitui um dos últimos episódios de uma lenda longa e complicada, "ou de um entrelaçamento de lendas" da mitologia grega. Filho de Áison, rei de Iolco, Jáson teria direito ao trono quando atingisse a

\footnotetext{
${ }^{1}$ Mestrando em Teoria Literária na Universidade Federal de Uberlândia - UFU. wilsonconvictor@yahoo.com.br
} 


\begin{tabular}{|l|l|l|l|l|l|l|}
\hline InterteXto & Uberaba & UFTM & $\begin{array}{l}\text { v. 3 } \\
\text { n. 2 }\end{array}$ & p. 82-106 & 2010 - jul. / dez. & ISSN 1981-0601 \\
\hline
\end{tabular}

maioridade. Enquanto seu filho era preparado para reinar, o rei entregou o poder a um primo, Pelias, que, posteriormente, recusar-se-ia a passá-lo a Jáson e desterraria Áison. (KURY, 1999, p. 11). Algum tempo depois, acompanhado de seus admiradores, Jáson apresenta-se a Pelias, exigindo de volta o trono. Intimidado, Pelias lembra que Aietes, rei da Cólquida, havia matado Frixo, parente de ambos, "para apossar-se do tosão (ou velocino) de ouro (pele de um carneiro prodigioso, alado e dotado de lã de ouro)". Dizendose idoso para empreender a vingança, Pelias exorta Jáson a realizá-la, prometendo-lhe a coroa, se ele regressar vitorioso.

Chegando à Cólquida com sua expedição (os "Argonautas", tripulantes da nau Argó), Jáson recebe de Aietes a promessa de que lhe seria entregue o tosão de ouro, na condição de que realizasse, num mesmo dia, "quatro proezas consideradas impossíveis", dentre elas, matar o dragão feroz que guardava noite e dia o tosão de ouro. A deusa Hera, que simpatizava com Jáson, teria feito a filha do rei Aietes, Medeia, apaixonar-se perdidamente por ele e prometer, "se este jurasse casar-se com ela e lhe garantisse fidelidade eterna, ajudá-lo a vencer, com seus poderes mágicos famosos na região, todas as provas sobre-humanas." Jáson promete fidelidade e casamento e recebe de Medeia as ervas e poções mágicas com que ele passa por todas as provas e se apossa do tosão de ouro. Logo depois, ele parte, levando Medeia consigo. (Id. p. 12). Furioso com a fuga de sua filha, Aietes manda seu filho em perseguição aos fugitivos. Medeia mata o irmão e espalha seu cadáver esquartejado "ao longo da rota da Argó para desnortear o pai quando este viesse também em sua perseguição."

Em Iolco, Medeia usa seus remédios mágicos para devolver a juventude ao pai de Jáson, para que ele também possa participar das festas que celebram a vitória de seu filho. Pelias, o usurpador do trono, também deseja ser rejuvenescido, mas, instigada por Jáson, Medeia dá às filhas do rei uma receita propositadamente errada, que o mata. Tão forte é a revolta da população contra Medeia e Jáson, que os dois têm que fugir para Corinto, onde 


\begin{tabular}{|l|l|l|l|l|l|l|}
\hline InterteXto & Uberaba & UFTM & $\begin{array}{l}\text { v. 3 } \\
\text { n. 2 }\end{array}$ & p. 82-106 & 2010 - jul. / dez. & ISSN 1981-0601 \\
\hline
\end{tabular}

vivem "em perfeita união durante dez anos." No final desse período, Jáson se apaixona por Glauce (ou Creusa), filha de Creonte, rei de Corinto, e repudia Medeia para poder se casar "com sua nova amada." (Id. p. 13).

É nesse ponto da história que se inicia Medeia, peça de Eurípedes, um dos três mais importantes tragediógrafos da Grécia antiga. Essa tragédia foi encenada pela primeira vez no ano 431 a.C., em Atenas, "depois de o dramaturgo Neofron haver apresentado a sua Medeia [...]", de cujos fragmentos que sobreviveram induz-se que Eurípedes "pode ter-se inspirado em seu colega mais velho [...]". (Id. p. 15).

\begin{abstract}
A tônica da Medeia é o ódio sobre-humano em que se transforma o amor da heroína por Jáson, quando este a repudiou para casar-se com a filha do rei da região que os acolhera. A essa humilhação terrível seguiu-se outra, que precipitou a decisão funesta de Medeia: Creonte, rei de Corinto e pai da nova noiva de Jáson, decretou a expulsão da infeliz Medeia e de seus filhos de seu reino. Medeia era conhecida nas lendas da Antiguidade por seus poderes mágicos extraordinários. Sua terra natal - a Cólquida de onde Jáson a trouxera -, era famosa pelas aptidões sobrenaturais de seus habitantes, feiticeiros hábeis e conhecedores de todos os segredos da magia. [...] Medeia, humilhada, confiante em seus poderes mágicos resolveu vingar-se de Jáson por todos os meios possíveis e em tudo que pudesse feri-lo. (Id. p. 13).
\end{abstract}

A personagem evolui de seu abatimento de esposa repudiada para uma mulher dominada por um "desejo de vingança e extermínio", que não se detém "diante do infanticídio, como vindita extrema para o aniquilamento completo do marido perjuro." (Id. ibid.). Mário da Gama Kury aponta que o pensamento de Medeia, de se vingar de Jáson, assassinando os filhos, é compreensível, em vista da "necessidade instintiva dos pais de se verem perpetuados nos filhos", ou seja, pelo desejo de dar continuidade à linhagem; ideia que é acentuada pelo episódio que mostra a ânsia de Egeu, rei de Atenas, de conseguir um filho de sua mulher. (Id. p. 15).

O tema de Medeia vem sendo retomado de tempos em tempos por dramaturgos que se seguiram, desde Sêneca até Corneille. Em português, 


\begin{tabular}{|l|l|l|l|l|l|l|}
\hline InterteXto & Uberaba & UFTM & $\begin{array}{l}\text { v. 3 } \\
\text { n. 2 }\end{array}$ & p. 82-106 & 2010 - jul. / dez. & ISSN 1981-0601 \\
\hline
\end{tabular}

Antonio José da Silva, chamado o Judeu, transformou o trágico em cômico na ópera Os Encantos de Medeia, que foi apresentada em Lisboa em maio de 1735. O carioca Agostinho Olavo foi o autor da primeira Medeia brasileira, numa adaptação da história ao contexto do país.

Em 1947, dez anos, portanto, antes de Olavo, o dramaturgo francês Jean Anouilh havia retomado o mito na peça Medée (Medeia). A relativa proximidade das datas de criação das duas obras daria margem a um estudo comparado entre elas. De acordo com um artigo de Ana Fernandes, se Anouilh

é fiel ao título do trágico grego e se conserva a trama da lenda, ele propõe, pelo contrário, uma heroína bem mais revoltada que a do seu antepassado. Embora [...] tenha criado uma tragédia tradicional que suscita o terror e a piedade, ele coloca o espectador face a uma violência verbal e gestual que era estranha aos autores clássicos. Nesta peça, onde inúmeras didascálias contêm o verbo "crier», em que Medeia cospe para cima de Creonte e violenta a sua ama, o trágico tem tendência para se transformar numa espécie de teatro cruel. É precisamente esta crueldade que dá uma certa originalidade à peça de Anouilh, e que serve para sublinhar a relação da personagem com os outros e consigo própria. (FERNANDES, 2004, p. 41).

Comentando uma fala em que a Medeia de Anouilh "reivindica [...] o facto de pertencer a uma raça e define claramente a sua personalidade, numa declinação lírica do nome" e "clama tanto mais a sua adesão a esta raça quanto ela evoca a sua ascendência e faz valer, face a Creonte, o peso da herança", Ana Fernandes menciona que a heroína "separa-se da comunidade para que possa tornar precisa a sua identidade", distinguindo-se do comum dos mortais. (Id. p. 45).

Na medida em que Medeia não proclama, em Eurípides, a sua adesão a uma raça de seres particulares, parece que Jean Anouilh quis dar-lhe, na sua peça, uma personalidade mais bem definida do que no seu modelo antigo. (Id. p. 46).

O autor brasileiro dá, igualmente, ênfase à diferença racial entre a feiticeira estrangeira e a sociedade na qual se instala. Agostinho Olavo 


\begin{tabular}{|l|l|l|l|l|l|l|}
\hline InterteXto & Uberaba & UFTM & $\begin{array}{l}\text { v. 3 } \\
\text { n. 2 }\end{array}$ & p. 82-106 & 2010 - jul. / dez. & ISSN 1981-0601 \\
\hline
\end{tabular}

ambienta o mito grego no Brasil colonial, no último quartel do século XVII. Pela narrativa, sabe-se que Jinga era rainha de uma tribo africana. Apaixonando-se por Jasão, um traficante de escravos, a rainha assassina o pai e o irmão e entrega seu povo ao domínio do homem estrangeiro, numa tentativa de agradar-Ihe. Depois disso, ela viaja ao Brasil como sua amante. Estabelecendo-se no novo país, torna-se muito requisitada como feiticeira, até o dia em que, a pedido de Jasão, promete nunca mais fazer uso de suas macumbas e rituais. É batizada, recebendo o nome de Medea, e passa a viver em uma ilha, desligando-se da comunidade, em que ela é desprezada tanto pela população branca como por seus compatriotas, agora escravizados. A peça traz a tensão, na personagem, entre o respeito àquela promessa e o seu desejo de voltar às práticas da feitiçaria, ao qual cederá somente ao saber da traição de seu amado, que pretende se casar com Creusa, moça branca, filha de um capitão. Medea dirigirá, então, a força de sua magia para a rival.

Em meu trabalho, aproximarei o texto da peça ao contexto no qual a história é ambientada, a saber, o Brasil colônia, buscando examinar o papel cumprido, tanto no contexto como no texto, pela figura da feiticeira, mediante pesquisas de Laura de Mello e Souza, Luiz Mott, Edison Carneiro, dentre outras fontes sobre o assunto.

Obter informações a respeito de Agostinho Olavo não é tarefa simples. Como fonte, encontrei somente um artigo online da Dra. Maria Cecília de Miranda Nogueira Coelho, que compara a peça Além do rio, primeira transposição da história de Medeia para o teatro brasileiro, ao espetáculo Gota D’água, outra releitura do mito grego, concebida em 1975 por Paulo Pontes e Chico Buarque.

Agostinho Olavo não era negro, mas estava ligado, com outros autores, ao Teatro Experimental do $\mathrm{Negro}^{2}$, um movimento estético-político que surgiu

\footnotetext{
${ }^{2}$ Mais informações sobre o Teatro Experimental do Negro no artigo Teatro experimental do negro: trajetória e reflexões, de Abdias do Nascimento, no endereço: http://www.scielo.br/scielo.php?script=sci arttext\&pid=S0103-40142004000100019
} 


\begin{tabular}{|l|l|l|l|l|l|l|}
\hline InterteXto & Uberaba & UFTM & $\begin{array}{l}\text { v. 3 } \\
\text { n. 2 }\end{array}$ & p. 82-106 & 2010 - jul. / dez. & ISSN 1981-0601 \\
\hline
\end{tabular}

nos anos quarenta. Segundo o artigo de Maria Cecília Coelho, o governo brasileiro impediu o Teatro Experimental do Negro de apresentar a peça Além do rio no Primeiro Festival Mundial das Artes Negras, de 1966, no Senegal, por não considerá-la representativa da cultura brasileira. O evento dependia de que cada país aprovasse as delegações que iria enviar. No caso do Brasil, o Ministério do Exterior não autorizou a viagem do grupo de teatro, enviando, em vez dele, um de capoeira.

O repúdio à atitude do governo foi manifestado por meio de carta de Abdias do Nascimento, criador e diretor do Teatro Experimental do Negro. Talvez, em função deste episódio, Além do Rio jamais tenha sido encenada por uma companhia profissional, e hoje é uma obra quase esquecida. (COELHO, 2008, pp. 4-5).

Analisando o problema da censura e da dificuldade de recepção da peça, Maria Cecília Coelho sugere o peso exercido pelo fato de Medea, uma mulher negra, assassinar duas crianças brancas - seus filhos com Jasão - afirmando, ao final, sua negritude de rainha africana, inclusive pela retomada do nome anterior. No julgamento da autora, a Medeia de Agostinho Olavo mostra-se, pela recusa em se submeter à humilhação imposta pela infidelidade de Jasão ou se entregar à morte, mais trágica e heroica que a de Gota D’água. (Id. pp. 5$6)$.

Entretanto não será focada aqui a questão racial presente na obra e, sim, o que nela se percebe das práticas de feitiçaria comuns no Brasil colônia. De acordo com Laura de Mello e Souza,

Numa sociedade escravista como a do Brasil colonial, a tensão era permanente, constitutiva da própria formação social, e refletia-se em muitas práticas mágicas e de feitiçaria exercidas pelos colonos. Através delas, buscava-se ora preservar a integridade física, ora provocar malefícios a eventuais inimigos. Tinham portanto função dupla: ofensiva, visando agredir; defensiva, visando preservar, conservar. (SOUZA, 1986, p. 194).

Recorria-se às feiticeiras, em especial, quando os exorcismos da Igreja e 


\begin{tabular}{|l|l|l|l|l|l|l|}
\hline InterteXto & Uberaba & UFTM & $\begin{array}{l}\text { v. 3 } \\
\text { n. } 2\end{array}$ & p. 82-106 & 2010 - jul. / dez. & ISSN 1981-0601 \\
\hline
\end{tabular}

os remédios dos boticários não surtiam efeito na cura de doenças. Não obstante a preocupação da Inquisição e da própria legislação real, que proibia a prática das feitiçarias e superstições, punindo-as com a excomunhão, com multas pecuniárias, com açoitamento, ou mesmo com o degredo para a África ou para as galés, lá estavam sempre "as rezadeiras, benzedeiras e adivinhos prestando tão valorizados serviços à vizinhança." (MOTT, 1997, pp. 194 a 196). Havia, ainda, os artifícios da magia erótica, utilizada a fim de obter ou conservar o amor: as orações amatórias, fórmulas dirigidas tanto aos santos como aos demônios; as cartas de tocar, "magia ibérica que se fazia por meio de um objeto gravado com o nome da pessoa amada e/ou outras palavras, o qual, encostado na dita pessoa, seria capaz de seduzi-la" (VAINFAS, 1997, p. 250). Emanuel Araújo refere os casos das feiticeiras Isabel Rodrigues (apelidada Boca Torta), que vendia "por cinco tostões a uma clientela carente de afeição" tais cartas de tocar, na forma de tirinhas de papel com "fórmulas infalíveis para conquistar o amor de outrem", e de Antônia Fernandes Nóbrega, especialista em beberagens, das quais uma se destinava a amigar desafetos: a cliente deveria encher três avelãs ou pinhões com unhas dos pés e das mãos, raspas das solas dos pés, cabelos de todo o corpo e mesmo uma unha do dedo mínimo do pé da própria bruxa; estando pronto este pavoroso manjar, ela o engoliria e, "depois de lançados por baixo", devolveria tudo a Antônia, que faria disso um pó a ser ingerido pelo homem, obviamente, sem que ele o soubesse. Semelhante resultado poder-se-ia conseguir, também, fazendo o homem engolir o próprio sêmen. Antônia ainda "fazia reacender nos maridos paixões apagadas, ensinando palavras (na verdade, expressões e frases) que, pronunciadas em certas circunstâncias, 'faziam endoidecer de amor e bemquerer [...]"' (ARAÚJO, 1997, p. 48).

Sortilégios que, consoante as palavras de Ronaldo Vainfas, revelam "o amálgama religioso cristão e pagão, irrigados no Brasil pelo fluxo de ingredientes culturais indígenas e africanos." (VAINFAS, 1997, p. 251).

Laura de Mello e Souza aponta a confecção de filtros, poções e 


\begin{tabular}{|l|l|l|l|l|l|l|}
\hline InterteXto & Uberaba & UFTM & $\begin{array}{l}\text { v. 3 } \\
\text { n. 2 }\end{array}$ & p. 82-106 & 2010 - jul. / dez. & ISSN 1981-0601 \\
\hline
\end{tabular}

unguentos para fazer querer bem e o recurso a sortilégios diversos que facilitassem as relações amorosas como um procedimento muito antigo, decorrendo, daí, que os juízes e inquisidores que trataram dos crimes de feitiçaria tenderam a sexualizá-lo e a tomar as bruxas, muitas vezes, como prostitutas ou semiprostitutas. (SOUZA, 1986, p. 227). Segundo Emanuel Araújo, a associação explícita entre feitiçaria e sexualidade tinha raízes "na crença de que os feitiços fabricados pelas bruxas eram úteis sobretudo no campo afetivo", conforme pareciam acreditar os legisladores civis e a Igreja, que proibiam àquelas mulheres o preparo de "beberagens para induzir qualquer indivíduo a "querer bem ou mal a outrem, ou outrem a ele." (ARAÚJO, 1997, p. 47).

Em Além do Rio, há uma personagem que procura o auxílio de Medea para seus problemas de infertilidade e impotência sexual.

EGEU - Trago-te cravo, noz moscada, flor de canela, âmbar e sedas finas do Zaipan.

MEDEA - Tantos presentes para quê?

EGEU - Para pedir outra vez. Medea, eu te suplico. [...] Nem no Zaipã nem na Índia encontrei quem me ajudasse. Só tu conheces o remédio...

MEDEA - Não posso. Por que insistes? Fui batizada e prometi a Jasão. [...].

EGEU - Dá-me filhos, Medea, como os teus. [...] Pelo filho que te peço, trocarei tudo o que tenho.

MEDEA - Nunca. É a minha promessa a Jasão.

EGEU - Gostas tanto dele assim?

MEDEA (quase consigo mesma) - Por ele traí a raça, deixei mortos pai e irmão.

EGEU - Em troca do filtro que pedi, terás o meu barco que vai partir para terras mais amigas, queres?

MEDEA - Por que partir para longe? Minha pátria é aqui nesta terra de Jasão. Mas por que me dizes isso? E eu por que sinto tanto medo? (OLAVO, 1961, p. 209-210).

As bruxas eram inimigas da sociedade, personificando tudo aquilo que se considerava antissocial - informa Souza; eram os indivíduos antissociais de fato, e que se encontravam no seio da sociedade. Na peça, esse isolamento da feiticeira é passado pela moradia de Medea: um casebre numa ilha, cujo único 


\begin{tabular}{|l|l|l|l|l|l|l|}
\hline InterteXto & Uberaba & UFTM & $\begin{array}{l}\text { v. 3 } \\
\text { n. 2 }\end{array}$ & p. 82-106 & 2010 - jul. / dez. & ISSN 1981-0601 \\
\hline
\end{tabular}

acesso era uma ponte sobre um rio profundo.

Alguns grupos sociais diferenciavam duas categorias: as bruxas noturnas e as bruxas cotidianas. As primeiras eram aquelas que viviam às voltas com voos, "metamorfoses, encruzilhadas, demônios que Ihes tomavam o sangue ou, familiares, alojavam-se no seu corpo, na sua casa, nas suas garrafas e utensílios domésticos", relacionando-se de perto com o misterioso universo sobrenatural. A classificação entre as bruxas cotidianas seria a mais apropriada para a Medea de Agostinho Olavo, pois é do tipo de bruxa que, "dividindo quintais com aqueles que a hostilizavam, adivinhando objetos perdidos, curando achaques e doenças, facilitando jogos amorosos, eram muitas vezes 'a imagem do vizinho que não se desejava ter'”. (SOUZA, 1975, pp. 241-242). Percebe-se que Medea cumpre esse papel naquela sociedade, pelo que dizem sobre ela duas lavadeiras a uma terceira, nova na região - um artifício usado, principalmente nas primeiras cenas, para apresentar a personagem:

I LAVADEIRA - É lugar mal-assombrado. Ninguém passa mais por lá.

III LAVADEIRA - Pra mim, ela fez macumba. [...] (OLAVO, 1961, p. 201).

I LAVADEIRA - Cuidado! É mulher perigosa.

III LAVADEIRA - Negra suja! Feiticeira! [...] Traiu toda a tribo e nunca se arrependeu.

I LAVADEIRA - Diz que é dona da ilha. Preguiçosa, não faz nada. Vive como as sinhás brancas, com uma mucama a seu lado. (Id. p. 202).

III LAVADEIRA - Não ria tão alto. Se nos ouve, é praga na certa. Conhece tanta mandinga e canjerê!... A gente pode ficar aleijada para sempre. Com essas coisas não se brinca. (Id. p. 202).

I LAVADEIRA - Até os negros que a odeiam têm um medo que se pelam. (Id. p. 203).

III LAVADEIRA - E todos vêm procurá-la para pedir mezinhas e canjerês.

I LAVADEIRA - E a todos ela enxota e diz que foi batizada e prometeu a Jasão nunca mais fazer macumbas nem candomblés." (Id. p. 206).

As referências a mandingas, canjerês, mezinhas, macumbas e 


\begin{tabular}{|l|l|l|l|l|l|l|}
\hline InterteXto & Uberaba & UFTM & $\begin{array}{l}\text { v. 3 } \\
\text { n. 2 }\end{array}$ & p. 82-106 & 2010 - jul. / dez. & ISSN 1981-0601 \\
\end{tabular}

candomblés $^{3}$ remetem às tradições religiosas e ritualísticas africanas de Medea. De acordo com Carlos Rodrigues Brandão, primeiro, como escravos, depois, como trabalhadores braçais, os negros sempre foram identificados pelos habitantes brancos como "tipos sociais e religiosos que oscilavam entre o socialmente condenável, quando praticantes de rituais e difusores de crenças tidas como estranhas ou misteriosas (o samba, o saravá, a macumba); e o culturalmente pitoresco, quando reprodutores populares de formas de saber e trabalho simbólico branco [...]" (BRANDÃO, 2007, p. 65). Conforme indica o diálogo das lavadeiras, Medea era tida como praticante de uma religião estranha e misteriosa, ligada à tradição do candomblé, portanto, socialmente condenável, seguindo as categorias definidas por Brandão.

Os candomblés são comunidades fechadas, que não obedecem a qualquer governo comum, nem a regras comuns. Por isso, a autoridade moral e espiritual emana direta e exclusivamente do pai ou da mãe de santo, que, acima de sua própria autoridade, só reconhece a dos orixás. ${ }^{4}$ (CARNEIRO, [19-], p. 137). "As mulheres detêm todas as funções permanentes do candomblé", enquanto aos homens cambem apenas as temporárias e as honorárias. (Id. p. 143). Ao assumir a chefia, a filha passa a mãe, na qual se resume toda a autoridade, já que os candomblés são igrejas independentes entre si. (Id. p. 127). Nada se faz sem a licença expressa do chefe. "A sua vontade é lei, que só ele mesmo poderá revogar ou modificar. Todo o peso da sua autoridade recai sobre as mulheres, invadindo mesmo o terreno particular, privado [...]." (Id. p. 132-133).

\footnotetext{
${ }^{3}$ Canjerê: 1 - Reunião de pessoas, geralmente de negros, para a prática de feitiçarias. 2 Feitiço, mandinga. 3 - Cerimônias religiosas africanas. 4 - Dança profana dos negros. (FERREIRA, 1975, p. 270).

Candomblé: As cerimônias religiosas anuais obrigatórias do culto. (CARNEIRO, [19--], p. 180). Mandinga: Feitiço, arte mágica. Termo nascido da fama de feiticeiros de que gozavam os negros mandês ou mandingas. (Id. p. 185).

Mezinha: Qualquer remédio caseiro. (FERREIRA, 1975, p. 920).

Macumba: 1 - Sincretismo religioso afro-brasileiro, derivado do candomblé, com elementos de várias religiões africanas, de religiões indígenas brasileiras e do crsitianismo. 2 - Ritual sincrético que lhe corresponde. 3 - Por derivação, magia negra. 4 - Bruxaria. (Id. p. 863).

${ }^{4}$ Orixá: Personificação e divinização das forças da natureza. (CARNEIRO, [19--], p. 187).
} 


\begin{tabular}{|l|l|l|l|l|l|l|}
\hline InterteXto & Uberaba & UFTM & $\begin{array}{l}\text { v. 3 } \\
\text { n. 2 }\end{array}$ & p. 82-106 & 2010 - jul. / dez. & ISSN 1981-0601 \\
\hline
\end{tabular}

Pelo diálogo entre as lavadeiras e por aquele entre a feiticeira e sua ama, entende-se que Medea era a chefe de um candomblé, cujos membros, agora sem sua autoridade, não sabem o que fazer e clamam por sua volta:

[...] De muito longe, da floresta, chega, em surdina, o batido ritmado de atabaques, tantãs marimbas e agogôs, tocando um ponto de macumba. (OLAVO, 1961, p. 200).

III LAVADEIRA - Não ouve os tambores? Estão chamando Medea. [...]

II LAVADEIRA - Mas chamando para quê?

III LAVADEIRA - Digo que é mãe de santo e os espíritos só baixam, quando é ela quem canta o ponto. (Id. p. 202-203).

MEDEA - [...] Mas por que me chamam assim? Por que não param de tocar?

AMA - É o tantã de nossa gente. É a nossa raça chamando a sua rainha Jinga.

MEDEA - Não me chame assim! Os brancos me batizaram Medea e eu prometi a Jasão. (Id. p. 204).

Os negros fugidos chamam pela mãe de santo por meio do ritmo tocado de atabaques, tantãs, marimbas e agogôs. ${ }^{5}$ Concorde com Edison Carneiro, o ritmo e o uso de instrumentos simples, de corda e de percussão, nas performances ritualísticas, em que a dança e o canto se ajustam harmonicamente, é uma característica marcante nos candomblés. Pela junção destes três elementos básicos, batuque-canto-dança, é que, nos rituais de possessão, cria-se o ambiente propício para a eficácia do ritual. (CARNEIRO, [19--] p. 166). A orquestra dos candomblés é composta por três instrumentos principais: o atabaque, o agogô e a cabaça, dos quais o primeiro é o mais importante:

Os atabaques são considerados essenciais para a invocação dos deuses. [...] Sem o atabaque, a festa perde $90 \%$ do seu valor, pois esse instrumento é considerado o meio de que se servem os humanos para as suas comunicações e para suas invocações aos orixás. É, ainda, como na África, o seu telégrafo, dando a grata notícia da festa à gente do candomblé por acaso distante. (Id. p. 105-106).

\footnotetext{
${ }^{5}$ Instrumentos de percussão de origem africana. (FERREIRA, 1975, p. 51, p. 890, p. 1353).
} 


\begin{tabular}{|l|l|l|l|l|l|l|}
\hline InterteXto & Uberaba & UFTM & $\begin{array}{l}\text { v. 3 } \\
\text { n. 2 }\end{array}$ & p. 82-106 & 2010 - jul. / dez. & ISSN 1981-0601 \\
\hline
\end{tabular}

Na peça, verifica-se, igualmente, a presença do canto e dos passos de dança, que Medea executa em dois momentos distintos. O primeiro no início, quando ela resiste ao chamado dos negros fugidos: sua cantoria, então, expressa o conflito interno entre o desejo de voltar aos rituais do candomblé e a promessa feita a Jasão.

[...] O tantã é cada vez mais rápido e Medea dá os primeiros passos do ponto como se uma força sobrenatural a impelisse.) MEDEA (cantando e dançando):

Anagogô... auê... auá.

Anagogô... auê... auá.

Ogun já chegou,

Ogun vai baixar. (OLAVO, 1961, pp. 203-204).

O segundo momento em que Medea canta é no final, quando, já havendo descoberto a traição do amante, envia de presente seu colar enfeitiçado a Creusa, retornando às práticas da magia. Interessante notar a mudança da divindade evocada, de Ogum (ou Ogun) para Exu:

MEDEA - [...] Vai, Batista, vai levar à bela noiva o presente da negra que está sozinha, não tem destino nem casa, não tem mais filhos nem amor.

(Batista, a princípio, admirado, recebe o colar e parte contente. Em surdina, voltam os tambores a bater na mata... Medea dá uma risada estridente e começa os passos de uma dança de macumba).

MEDEA:

Anauê... agogô.

Anauê... agogô.

Exu já chegou,

Exu vai baixar.

(Da floresta, o coro responde, sempre num crescente até atingir o paroxismo). (Id. p. 219).

As lendas africanas recolhidas por Pierre Verger relatam que Ogum era um guerreiro temível e sanguinário, o mais velho e mais combativo dos filhos de Odudua, conquistador de Ifé. "Por isto, tornou-se o regente do reino quando Ododua, momentaneamente, perdeu a visão." Ogum lutava incessantemente contra os reinos vizinhos, trazendo "sempre um rico espólio de suas 


\begin{tabular}{|l|l|l|l|l|l|l|}
\hline InterteXto & Uberaba & UFTM & $\begin{array}{l}\text { v. 3 } \\
\text { n. 2 }\end{array}$ & p. 82-106 & 2010 - jul. / dez. & ISSN 1981-0601 \\
\hline
\end{tabular}

expedições, além de numerosos escravos." (VERGER, 1997, p. 14).

Ogum, o valente guerreiro,

o homem louco dos músculos de aço!

Ogum, que tendo água em casa,

lava-se com sangue!

Os prazeres de Ogum são o combate e as brigas.

O terrível orixá, que morde a si mesmo sem dó!

Ogum mata o marido no fogo e a mulher no fogareiro.

Ogum mata o ladrão e o proprietário da coisa roubada! (Id. p. 16).

No livro Iniciação à Umbanda, Dandara e Zeca Ligiéro comentam que, no sincretismo religioso brasileiro, Ogum é associado a São Jorge. De personalidade fortemente guerreira, é conhecido entre os fiéis e sacerdotes como "santo forte", "vencedor de batalhas", "general da Umbanda", "soldado da cavalaria". A energia de Ogum deve ter abençoado os negros que abriram caminho para longe da escravidão. (DANDARA; LIGIÉRO, 2000, p. 120).

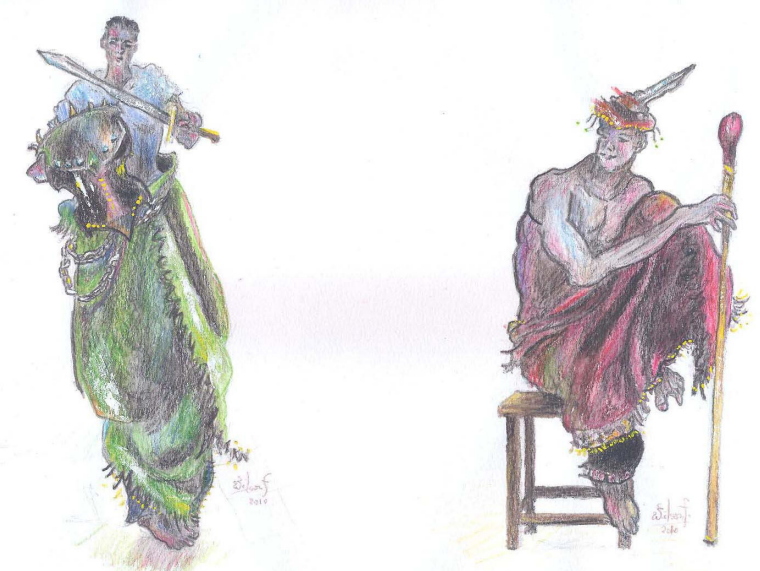

Figura 1 - Wilson Filho: Ogum e Exu. Fonte: Acervo do autor.

Já Exu é o mais sutil e astuto de todos os orixás. "Ele aproveita-se de suas qualidades para provocar mal-entendidos e discussões entre as pessoas ou para preparar-Ihes armadilhas." (VEGER, 1997, p. 11). Mais do que somente ajudar na realização dos desejos humanos, Exu os atiça e excita, para que eles se manifestem. "O prêmio que ele oferece aos seus seguidores é o 


\begin{tabular}{|l|l|l|l|l|l|l|}
\hline InterteXto & Uberaba & UFTM & $\begin{array}{l}\text { v. 3 } \\
\text { n. 2 }\end{array}$ & p. 82-106 & 2010 - jul. / dez. & ISSN 1981-0601 \\
\hline
\end{tabular}

gozo fugaz dos sentidos, alcançado através de coisas como o dinheiro e o sexo. Não é de se admirar que ele seja sincretizado com Satã." (DANDARA; LIGIÉRO, 2000, p. 139). Exu pode fazer coisas extraordinárias; por exemplo, ele "pode ter matado um pássaro ontem, com uma pedra que jogou hoje!" Torna-se muito malvado se as pessoas se esquecem de homenageá-lo; por isso, é necessário que se façam sempre oferendas a Exu, antes de qualquer outro orixá. (VERGER, 1997, p. 11). "Pois Exu pode ser o mais benevolente dos orixás se tratado com consideração e generosidade." (Id. p. 13).

É a esse poderoso orixá que a feiticeira se dirige ao lançar o seu encantamento de morte. Se, como esclarece o texto de Laura de Mello e Souza, os talismãs e as bolsas de mandinga "inserem-se no que Etienne Delcambre designou como lei de contato", ou seja, quando, do ponto de vista da magia, fluidos benéficos emanam do talismã ou dos objetos acondicionados dentro da bolsa (SOUZA, 1986, p. 213), é possível pensar que a mesma lei poderia reger o sortilégio que Medea aplica ao colar enviado a Creusa, embora, aqui, os fluidos sejam maléficos. Pela leitura de Roger Bastide, a autora mostra que,

no seio do sistema escravista, a cultura africana deixou de ser 'a cultura comunitária de uma sociedade global para se tornar a cultura exclusiva de uma classe social - de um único grupo da sociedade brasileira, explorado economicamente, subordinado socialmente.' [...]

Neste contexto, a magia maléfica, ou feitiçaria, tornou-se uma necessidade na formação social escravista. Ela não apenas dava armas aos escravos para moverem uma luta surda muitas vezes, a única possível - contra os senhores como também legitimava a repressão e a violência exercida sobre a pessoa do cativo. (Id. p. 204).

Havia mesmo atos de violência extrema contra as feiticeiras, na crença de que, assim, se desfariam seus feitiços. No Brasil, essa crença no poder redentor e purificador da violência física encontrou uma poderosa aliada na necessidade escravista do castigo exemplar; os escravos podiam ser 


\begin{tabular}{|l|l|l|l|l|l|l|}
\hline InterteXto & Uberaba & UFTM & $\begin{array}{l}\text { v. 3 } \\
\text { n. 2 }\end{array}$ & p. 82-106 & 2010 - jul. / dez. & ISSN 1981-0601 \\
\end{tabular}

legitimamente castigados por serem feiticeiros. "Enxergá-los como feiticeiros, por sua vez, foi uma das manifestações da paranóia da camada senhorial da colônia." (Id. p. 205).

Frequentemente, as denúncias de feitiçaria refletiam tensões existentes entre vizinhos, conhecidos ou inimigos. "Como na Europa, questões miúdas, falatórios de vilarejo acabavam servindo de base a denúncias e à constituição de testemunhos." Construindo-se coletivamente o estereótipo da bruxa, encontrava-se um meio de resolver os conflitos internos à vida da comunidade, "identificando e excluindo o responsável pela desgraça." Mas nem todas as feiticeiras se escondiam com medo da perseguição; muitas se vangloriavam de seus poderes ante a vizinhança, como forma de atrair clientes e conseguir algum dinheiro que Ihes garantisse a sobrevivência. (Id. p. 197). Emanuel Araújo afirma que, apesar da proibição da Igreja a qualquer feitiçaria destinada a influir no sentimento alheio e a interferir nas vontades, as feiticeiras eram teimosas. "Na década de 1590, antes da chegada do Santo Ofício, elas eram muito ativas em Salvador: manipulavam anseios, reforçavam crenças, aguçavam ardores." De alcunha Arde-lhe o Rabo, uma bruxa dessa época alardeava em público suas funções, dizendo que, à meia noite, em seu quintal, nua da cintura para cima, ela falava com o Diabo, "o que só fazia atiçar o imaginário ligado aos sabás, reuniões em que as feiticeiras entregavam-se ao Diabo em cópulas fantásticas" (ARAÚJO, 1997, p. 48).

Quando ainda praticante, apesar de muito requisitada como feiticeira, Medea causou, por outro lado, o ódio da população, devido às macumbas geradas por seu gênio ciumento. O que a salvou foi a proteção do amante branco. Assim comenta Creonte, pai de Creusa, quando vai exigir a partida da rival da filha:

CREONTE - És uma negra trazida por um vendedor de escravos poderoso, que te protegeu contra toda a população. Já te esqueceste dos despachos que fizeste, das mandingas e candomblés e tantos males que espalhaste pelo arraial com os teus ciúmes? 


\begin{tabular}{|l|l|l|l|l|l|l|}
\hline InterteXto & Uberaba & UFTM & $\begin{array}{l}\text { v. 3 } \\
\text { n. } 2\end{array}$ & p. 82-106 & 2010 - jul. / dez. & ISSN 1981-0601 \\
\hline
\end{tabular}

MEDEA - Mas depois fui batizada e prometi a Jasão. Nunca mais fiz os trabalhos que os brancos vêm me pedir. (OLAVO, 1961, p. 217).

Creonte, entretanto, sabe que, vendo-se separada de Jasão, Medea não mais terá motivos para cumprir a promessa. Em Eurípedes, o receio do rei surge principalmente em razão das ameaças proferidas por Medeia. O capitão Creonte de Agostinho Olavo retira seus temores do que já conhece do caráter ciumento e vingativo de Medea.

CREONTE - É uma ordem, Medea. Jasão vai casar-se com minha filha e és capaz de quebrar a promessa feita e, com um filtro, uma mandinga qualquer... procurar uma vingança. [...] Tenho medo que esqueças as promessas que fizeste e causes algum mal a minha filha. Tu és hábil. Conheces os mil feitiços e todos os canjerês. Os brancos conhecem o teu gênio e sabem que procurarás vingança. Tu não sabes perdoar. (Id. Ibid.).

Diferença resultada, em parte, das estruturas de enredo de cada uma das peças. Quando a tragédia do autor grego se inicia, Medeia já sabe da traição do esposo; ela chora e o amaldiçoa, como também amaldiçoa o rei e sua filha. Isso é o que desperta o temor de Creonte, que decretará o exílio de quem o ameaça: "és hábil e entendida em mais de um malefício / e sofres hoje por te veres preterida / no leito conjugal. Ouço dizer - transmitem-me - / que vens ameaçando atentar contra a vida do pai que prometeu a filha, do marido / e da segunda esposa." (EURÍPEDES, 1999, p. 30). Igualmente, Jáson chama a atenção de Medeia para esse fato: "Tu, ao invés de refreares a loucura, I injuriavas dia e noite o soberano. / Agora expulsam-te por isso da cidade." (Id. p. 36).

Por outro lado, em Além do rio, Medea apenas saberá da traição do amante na metade da peça. Ela não terá tempo para lamentações nem ameaças, pois, quando Creonte aparecer exigindo sua retirada, ela terá acabado de saber a notícia do noivado de Jasão. À semelhança da Medeia grega, ela, hipocritamente, aceitará a ordem, implorando apenas por mais um dia de permanência. Para a personagem de Eurípedes, esse prazo serviria 


\begin{tabular}{|l|l|l|l|l|l|l|}
\hline InterteXto & Uberaba & UFTM & $\begin{array}{l}\text { v. 3 } \\
\text { n. 2 }\end{array}$ & p. 82-106 & 2010 - jul. / dez. & ISSN 1981-0601 \\
\hline
\end{tabular}

para pensar no lugar de exílio e nos recursos para sustentar os filhos. (Id. p. 32). A Medea africana, que deveria partir sozinha, pede esse dia para se despedir dos filhos. Creonte aceita, sem desconfiar dos planos da feiticeira, que, enciumada e traída, sente-se agora desobrigada de sua promessa e livre para usar seu poder.

MEDEA - Branco estúpido! Acreditou no que eu disse! (pausa) A minha cama está fria, pois há dez luas, Jasão não vem. Mas não dormirá na cama de outra mulher. A noiva vai conhecer as mandingas que, um dia ela mesma veio aqui mendigar. (tira do pescoço o colar e começa a encantá-lo). Agora sei de que riam as lavadeiras da margem. Medea, filha de um rei e descendente do sol, não pode se sujeitar às zombarias como uma escrava qualquer. Querem que parta sozinha e deixe meus filhos para o amor de Jasão. Estes filhos malditos, nascidos de mãe funesta, já não podem mais viver. Eles que me tornam quase branca, são a luz da minha sombra, a vida de minha vida, mas também da de Jasão. E ele há de ficar sozinho para amaldiçoar o dia em que pensou poder tomar o coração que me deu. (Id. pp. 218-219).

Ainda que seja uma vingança direcionada a Jasão, a filha de Creonte acabará se tornando uma de suas vítimas: Medea enviará o presente encantado que matará Creusa em plena festa de noivado. A morte da noiva não é narrada, como na tragédia grega, mas mostrada em um quadro que separa o primeiro do segundo ato. A seguir, a negra pedirá aos dois filhos que, a fim de irem buscar presentes na aldeia, atravessem o rio, de cuja perigosa profundeza ela tem conhecimento. Vale lembrar a crença de que as bruxas são assassinas de crianças, uma das crenças mais generalizadas na Europa, no que dizia respeito às bruxas. (SOUZA, 1986, p. 201). Numa época em que grande número de crianças morria em decorrência da falta de cuidado dos pais, atribuir mortes desse tipo às feiticeiras talvez correspondesse ao "mecanismo aliviador de tensões e de culpas. [...] O pânico do infanticídio perdurou na mentalidade popular. Crianças doentes e raquíticas eram tidas como chupadas pelas bruxas." (Id. pp. 201-202). De início, Medea não confessa seus propósitos, dos quais as lavadeiras desconfiam com receio. 


\begin{tabular}{|l|l|l|l|l|l|l|}
\hline InterteXto & Uberaba & UFTM & $\begin{array}{l}\text { v. 3 } \\
\text { n. 2 }\end{array}$ & p. 82-106 & 2010 - jul. / dez. & ISSN 1981-0601 \\
\end{tabular}

II LAVADEIRA - Pára, Medea e pensa!

III LAVADEIRA - Medea, Medea, ainda há tempo! [...]

MEDEA - Como? Falam comigo? O que querem aqui? As brancas já falam com a preta? Não ousem se aproximar.

I LAVADEIRA - Medea, ainda há tempo. São teus filhos mulher.

MEDEA - Filhos meus, lindos... lindos... mas também os de Jasão.

III LAVADEIRA - Medea, por piedade! Também somos mãe, mulher. A nossa cor não importa. [...]

MEDEA - Mas de que falam vosmicês? Mandei meus filhos buscar presentes para que cheguem ao povoado como os reis da minha terra em visita a outro rei.

I LAVADEIRA - A correnteza é forte, as águas fundas e as pedras cheias de limo... nunca chegarão do outro lado. São teus filhos, mulher:

(Ouve-se um fraco grito, vindo do rio. As lavadeiras escondem os rostos e, chorando, vão-se afastando. [...] (OLAVO, 1961, p. 228).

A água é um elemento muito importante na mitologia africana. Muitas divindades estão ligadas ao rio. Oxum e Obá, respectivamente a segunda e a terceira das esposas de Xangô, após uma briga entre elas, temendo a fúria do marido, ambas fugiram e se transformaram em rios. "Até hoje, as águas destes rios são tumultuadas e agitadas no lugar de sua confluência, em lembrança da briga que opôs Oxum e Obá pelo amor de Xangô." (VERGER, 1997, p. 49). Oxum tem humor variável; por vezes, suas águas são calmas e permitem que sejam atravessadas por numerosos vãos, outros dias, elas são tumultuadas e violentas, inundando campos e florestas e não permitindo que ninguém as atravesse. (Id. pp. 42-44). Filha de Olokum, a deusa do mar e rainha das águas, lemanjá foi levada ao oceano por um rio, nascido quando quebrou uma garrafa contendo uma poção mágica, que recebera de sua mãe. (Id. pp. 50-52). Ainda há Nana Baruku, "velhíssima divindade das águas", e Olossá, senhora da lagoa (Id. pp. 62-53). Orixá caçador e guerreiro, Erinlê possuía um talismã, e, a qualquer momento, "ele poderia, graças a este talismã, transformar-se em água. Quando ele assim o desejasse." Transformando-se em rio, Erinlê encontrou-se com Oxum. "Ali onde se encontraram, o leito destes rios é suave 


\begin{tabular}{|l|l|l|l|l|l|l|}
\hline InterteXto & Uberaba & UFTM & $\begin{array}{l}\text { v. 3 } \\
\text { n. } 2\end{array}$ & p. 82-106 & 2010 - jul. / dez. & ISSN 1981-0601 \\
\hline
\end{tabular}

- eles estão felizes. Suas águas formaram um grande rio e o curso de ambos tornou-se um mesmo." (Id. pp. 20 a 23).

Oferendas destinadas a esses orixás eram feitas aos rios. Há, por exemplo, a lenda do rei Olowu, que sacrificou sua esposa a Oxum, em conseqüência de uma promessa mal entendida. Dirigindo-se para guerra, Olowu prometeu boas coisas (nkan rere) a Oxum, em troca de uma travessia calma pelo rio. Mas Oxum entendeu que ele falava de sua mulher, Nkan, filha do rei de Ibadan. (Id. p. 44). Ao voltar vitorioso da guerra, "Olowu mandou jogar sobre as vagas [do rio] toda sorte de boas coisas, as nkan rere prometidas [...] Mas Oxum devolveu todas estas coisas boas sobre as margens. Era Nkan, a mulher de Olowu, que ela exigia. Olowu foi obrigado a submeter-se e jogar sua mulher nas águas." (Id. p. 45).

Pode-se mesmo interpretar a morte dos filhos de Medea como um sacrifício oferecido aos deuses invocados, embora a relação com as águas do rio possa ser feita apenas indiretamente: Antes de se apaixonar por Xangô, Oxum era uma das esposas de Ogum.

O artigo de Maria Regina Candido informa que, segundo alguns mitógrafos, na versão do mito anterior ao século $V$ a. C., os filhos de Medeia eram mortos pela população de Corinto, em vingança à morte dos soberanos (Glauce e Creonte). Eurípedes teria sido quem "estabeleceu uma nova vertente mítica mostrando que as crianças haveriam sido executadas como sacrifício aos deuses" pela própria mãe. (CANDIDO, [20--], p. 5). Assim, na tragédia grega, o assassinato dos filhos constituiria tanto uma vingança contra Jáson, extinguindo sua descendência, como também um sacrifício aos deuses (Medeia leva seus corpos ao santuário de Hera) e, ainda, uma tentativa de protegê-los de serem mortos pela população de Corinto.

Em Além do rio, pode-se entender a morte dos meninos somente como sacrifício e como vingança enciumada, mas não como um ato de proteção contra a sociedade, pois Jasão, - homem poderoso que havia conseguido proteger a própria Medea contra a população irritada por seus ciúmes e feitiços 


\begin{tabular}{|l|l|l|l|l|l|l|}
\hline InterteXto & Uberaba & UFTM & $\begin{array}{l}\text { v. 3 } \\
\text { n. 2 }\end{array}$ & p. 82-106 & 2010 - jul. / dez. & ISSN 1981-0601 \\
\hline
\end{tabular}

- planejara acolher os filhos sob seu abrigo, plano que não mudaria, mesmo após a morte de sua noiva. O Creonte de Eurípedes determina o exílio de todos: "Medeia, [...], sai deste lugar para o exílio / com teus dois filhos!" (EURÍPEDES, 1999, p. 29). O Creonte de Agostinho Olavo, pelo contrário, proíbe a mãe de levá-los:

\begin{abstract}
CREONTE - [...] Tens que partir. [...].
MEDEA - Os meus filhos não estão preparados.

CREONTE - Os teus filhos não vão contigo.

MEDEA - Partirei, não fale mais. Mas vosmicê não pode separar-me dos filhos... [...] Essas crianças são minhas, são a luz da minha sombra, o calor do meu calor. Corte-me os braços e as pernas, marque-me com ferro em brasa, ou mande-me chicotear; mas não me tome os filhos, eles são partes dos pais... a minha continuação.

CREONTE - Dizes bem, mulher. Os filhos são parte dos pais. Mas os teus nasceram brancos e alforriados na pia, só pertencem a Jasão. Procura compreender. [...]. (OLAVO, 1961, p. 218).
\end{abstract}

A intenção de Jasão era cuidar dos filhos, e havia pensado no casamento com uma moça de família importante a fim de proporcionar-lhes uma vida melhor. É o que demonstram suas palavras, quando, após a morte da noiva, ele retorna à ilha de Medea para buscá-los.

JASÃO - Depois de mais esse crime, só te resta fugir! Fuja
Medea, fuja. [...] Fuja, mas deixe-me os filhos. Eles são
brancos, mulher.
MEDEA - São meus filhos muito mais.
JASÃO - Um dia te verão preta e vão perguntar espantados o
que fazem junto a ti. [...] Não podes compreender. Com o meu
casamento com Creusa, queria dar a meus filhos uma nobre
posição. Dá-me os meus filhos, Medea. (OLAVO, 1961, pp.
229-230).

Defendendo-se das acusações de Medeia, o Jáson de Eurípedes expõe um plano semelhante ${ }^{6}$, no qual havia pensado ao conceber seu casamento com a filha do rei; mas, ao contrário do Jasão de Olavo, ele desiste ao primeiro empecilho, provocado pelas ameaças de Medeia. Apesar de seus planos

\footnotetext{
${ }^{6}$ Conferir: EURÍPEDES, 1999, p. 29.
} 


\begin{tabular}{|l|l|l|l|l|l|l|}
\hline InterteXto & Uberaba & UFTM & $\begin{array}{l}\text { v. 3 } \\
\text { n. } 2\end{array}$ & p. 82-106 & 2010 - jul. / dez. & ISSN 1981-0601 \\
\hline
\end{tabular}

iniciais, após o decreto do rei, Jáson nada faz para defender os filhos do banimento. Isso se reflete no diálogo entre a Ama de Medeia e o preceptor:

PRECEPTOR - Ouvi dissimuladamente uma conversa, / [...] diziam / que os filhos iam ser expulsos de Corinto, / e a mãe com eles, por Creonte, nosso rei. [...]

AMA - E deixará Jáson tratarem desse modo / os filhos, apesar do desentendimento / que se manifestou entre a mãe deles e ele?

PRECEPTOR - Cede a aliança antiga em face de uma nova / e ele já não se mostra amigo desta casa. (EURÍPEDES, 1999, p. 22).

Em suma, Além do rio apresenta um Jasão e um Creonte mais preocupados com a criação dos meninos, nos quais não deveria cair o mesmo destino da mãe. Tal preocupação, muito provavelmente, resultava do fato de as crianças serem brancas, o que era, aos olhos de uma sociedade racista, uma barreira que as separava da mãe. Assim, essa visível diferença racial impediria, pelo menos em parte, que o ódio da população se voltasse contra os filhos de Medea.

Contudo, voltando a Eurípedes, é preciso não exagerar o amor de Medeia pelos filhos, na interpretação de que seu assassinato seria uma eutanásia que os protegeria de um linchamento, encarando-o antes como um ato de amor para com os filhos que de vingança para com Jáson. ${ }^{7}$ Afinal, aquele foi um procedimento necessário apenas devido à obstinação de Medeia por sua vingança. Tivesse ela saído de Corinto com humildade, tivesse sido sincera no pedido ao rei e à Glauce, e seus filhos poderiam ter permanecido, criando-se em casa nobre, sob a proteção do pai. Ou, ainda, Medeia poderia tê-los levado consigo, ao degredo que, ao menos, contaria com a acolhida de Egeu. A tragédia, porém, apresenta o conflito na feiticeira entre seu amor pelos filhos e

\footnotetext{
${ }^{7}$ Interpretação que tira uma de suas bases no monólogo de Medeia pouco antes do sacrifício: "[...] Ai! Ai! Nunca, meu coração! Não faças isso! / Deves deixá-los, infeliz! Poupa as crianças! / Mesmo distantes serão tua alegria. / Não, pelos deuses da vingança nos infernos! / Jamais dirão de mim que eu entreguei meus filhos / à sanha de inimigos! Seja como for, / perecerão! Ora: se a morte é inevitável, eu mesma, que Ihes dei a vida, os matarei!" (Id. p. 61).
} 


\begin{tabular}{|l|l|l|l|l|l|l|}
\hline InterteXto & Uberaba & UFTM & $\begin{array}{l}\text { v. 3 } \\
\text { n. 2 }\end{array}$ & p. 82-106 & 2010 - jul. / dez. & ISSN 1981-0601 \\
\hline
\end{tabular}

seu ódio por Jáson, este último saindo vencedor:

[...] Não! Não posso! / Adeus, meus desígnios de há pouco! Levarei / meus filhos para fora do país comigo. / Será que apenas para amargurar o pai / vou desgraçá-los, duplicando a minha dor? / Isso não vou fazer! Adeus, meus planos... Não! / Mas que sentimentos são estes? Vou tornar-me / alvo de escárnio, deixando meus inimigos / impunes? / Não! Tenho de ousar! [...] (EURÍPEDES, 1999, p. 61).

Além do rio também traz esse conflito: por um lado, o amor de Medea pelos filhos, de outro, o ciúme ${ }^{8}$ e o desejo de vingança.

MEDEA - Não vês? Lá, longe, no rio. Não vês os corpos boiando? Vá buscá-los, Jasão.

JASÃO - Não! Não! Não é possível! És um monstro, Medea! Mataste os teus próprios filhos, porque sabias que sem eles eu não posso mais viver.

MEDEA - Não. Tu vais viver. É o teu castigo.

JASÃO - [...] parto pela vida afora, chorando o destino cruel dos filhos por mim gerados, crianças que alimentei e que amava como nunca amei ninguém. (OLAVO, 1961, p. 230).

MEDEA - Eu os amava como tu. [...] Tu envelhecerás sem coração e sem risos, porque pensaste em tomar o amor que me havias dado... mas matando os meus filhos, matei também esse amor... ninguém o possuirá. [...] $E$ nem mesmo a sepultura deles será tocada por tuas mãos, já os levam as águas que não voltam nunca mais. Vão ao encontro da fonte eterna e da grande solidão, pois lá, a perder de vista, as águas do grande rio vão misturar-se às do mar.

JASÃO - E o rio será lembrado e será o rio maldito por todos os que mais tarde ouvirem a sua história.

MEDEA - E o rio será lembrado e será rio sagrado. Suas águas rolando vão sempre dizendo que não há maior glória que a que se alcança em não se deixar vencer. (ld. p. 231).

Ao final, Medea reassume seu posto de rainha, feiticeira e mãe de santo, aceitando a raça que anteriormente havia negado. Diferente da Medeia clássica, ela não foge. Permanece na ilha, confiando no apoio que encontraria nos escravos fugidos, membros do candomblé, que se escondem na floresta.

\footnotetext{
${ }^{8}$ Lembre-se da fala de Medea, já citada: "Querem que parta sozinha e deixe meus filhos para o amor de Jasão. Estes filhos malditos, nascidos de mãe funesta, já não podem mais viver. Eles que me tornam quase branca, são a luz da minha sombra, a vida de minha vida, mas também da de Jasão. $E$ ele há de ficar sozinho para amaldiçoar o dia em que pensou poder tomar 0 coração que me deu." (OLAVO, 1961, pp. 218-219).
} 


\begin{tabular}{|l|l|l|l|l|l|l|}
\hline InterteXto & Uberaba & UFTM & $\begin{array}{l}\text { v. 3 } \\
\text { n. 2 }\end{array}$ & p. 82-106 & 2010 - jul. / dez. & ISSN 1981-0601 \\
\hline
\end{tabular}

MEDEA - [...] Ó vozes da minha raça, ó minhas vozes, onde estão? Por que se calam agora? A negra largou o branco. Medea cospe este nome e Jinga volta a sua raça, para de novo reinar.

(Lentamente começam os atabaques, os tantãs e os agogôs a tocar um ponto de macumba. [...] Vultos se recortam entre as árvores. São negros fugidos, seminus, que numa macumba sangrenta festejam a volta de Medea à raça).

MEDEA - Ainda tocam o ponto. Ainda precisam de mim. Ainda sou rainha. Ainda sou preta e orixá. (Id. ibid.).

Muitos são os ângulos pelos quais os pesquisadores da literatura poderão abordar essa peça de Agostinho Olavo. Entre as possibilidades de estudo, algumas nas quais toquei levemente, aponto a análise comparada com o teatro clássico sobre o tema, principalmente com a tragédia de Eurípedes, em que se perceberá que, no Brasil, assim como em Corinto, a personagem representa o arquétipo da feiticeira: a mulher que veio do estrangeiro, de uma terra considerada bárbara e com tradições que dizem respeito às práticas mágicas; o isolamento e as tensões com a população, ainda que essa mesma sociedade procure, quando necessário, o auxílio de seus poderes; a manipulação de ervas e o culto aos deuses.

Além do rio (Medea) apresenta, além do tema da feitiçaria, no qual me detive especialmente neste artigo, interessante interpretação sobre as tensões raciais no Brasil do século XVII. Poder-se-á, também, fazer a comparação com a obra de Jean Anouilh e o paralelo com as duas adaptações, posteriores à de Agostinho Olavo, do mito de Medeia ao cenário brasileiro - a saber, a Medeia, de Oduvaldo Vianna Filho (o Vianinha), e Gota D’água, de Paulo Pontes e Chico Buarque, que trazem uma feiticeira também ligada às magias africanas; vale, outrossim, a observação do contexto em que a obra foi criada. Esquecida em decorrência da censura do regime militar, a peça de Agostinho Olavo merece ser lida e encenada, além de constituir valioso objeto de pesquisa e estudo.

\section{Referências}




\begin{tabular}{|l|l|l|l|l|l|l|}
\hline InterteXto & Uberaba & UFTM & $\begin{array}{l}\text { v. 3 } \\
\text { n. 2 }\end{array}$ & p. 82-106 & 2010 - jul. / dez. & ISSN 1981-0601 \\
\end{tabular}

ARAÚJO, Emanuel. Arte da sedução: sexualidade feminina na Colônia. In: PRIORE, Mary Del (org.) História das mulheres no Brasil. São Paulo: Contexto, 1997. 2. Ed.

BRANDÃO, Carlos Rodrigues. Os Deuses do Povo - Um Estudo Sobre a Religião Popular. Uberlândia: Edufu, 2007. $3^{a}$ edição ampliada com depoimentos.

CANDIDO, Maria Regina. O Saber Mágico de Medeia. In. Revista Mirabilia 1. [20--] Disponível em:

http://www.revistamirabilia.com/Numeros/Num1/medeia.html Acesso em: $25 / 06 / 2010$

CARNEIRO, Edison. Candomblés da Bahia. [S.I]: Ediouro, [19--].

COELHO, Maria Cecília de Miranda Nogueira. Por que Chico Buarque e Paulo Pontes mataram Medéia? In. Fazendo Gênero 8 - Corpo, Violência e Poder. Florianópolis, de 25 a 28 de Agosto de 2008. Disponível em:

http://www.fazendogenero8.ufsc.br/sts/ST70/Maria_Cecilia_de_Miranda_Nogue ira_Coelho_70.pdf Acesso: 17/04/10

DANDARA; LIGIÉRO, Zeca. Iniciação à Umbanda. Rio de Janeiro: Nova Era, 2000.

EURÍPEDES. Medeia. In. Medeia. Hipólito. As Troianas. Rio de Janeiro: Jorge Zahar, 1999. $4^{a}$ edição. Tradução do grego, apresentação e notas de Mário da Gama Kury.

FERNANDES, Ana. Dois mitos antigos revisitados por Jean Anouilh. In. Máthesis 13 2004, pp. 35-46. Disponível em: http://www4.crb.ucp.pt/biblioteca/Mathesis/Mat13/Mathesis13 35.pdf Acesso em: 26/06/2010.

FERREIRA, Aurélio Buarque de Holanda. Novo Dicionário da Língua Portuguesa. Rio de Janeiro: Editora Nova Fronteira, 1975.

KURY, Mário da Gama. Introdução. In. Eurípedes. Rio de Janeiro: Jorge Zahar, 1999.

MOTT, Luiz. 5. Cotidiano e vivência religiosa: Entre a capela e o calundu. In: 


\begin{tabular}{|l|l|l|l|l|l|l|}
\hline InterteXto & Uberaba & UFTM & $\begin{array}{l}\text { v. 3 } \\
\text { n. } 2\end{array}$ & p. 82-106 & 2010 - jul. / dez. & ISSN 1981-0601 \\
\hline
\end{tabular}

SOUZA, Laura de Mello e (org.). História da vida privada no Brasil. Volume 1: Cotidiano e vida privada na América portuguesa. São Paulo: Companhia das Letras, 1997.

OLAVO, Agostinho. Além do rio (Medea). In: NASCIMENTO, Abdias. Dramas para negros e prólogo para brancos: Antologia de teatro negro-brasileiro. Rio de Janeiro: Teatro Experimental do Negro, 1961.

SOUZA, Laura de Mello e. O diabo e a terra de Santa Cruz - Feitiçaria e religiosidade popular no Brasil colonial. São Paulo: Companhia das Letras, 1986.

VAINFAS, Ronaldo. 5. Moralidades brasílicas: Deleites sexuais e linguagem erótica na sociedade escravista. In: SOUZA, Laura de Mello e (org.) 0 diabo e a terra de Santa Cruz - Feitiçaria e religiosidade popular no Brasil colonial. São Paulo: Companhia das Letras, 1986.

VERGER, Pierre Fatumbi. Lendas Africanas dos Orixás. Salvador: Corrupio, 1997. 4ª ed. Tradução de Maria Aparecida da Nóbrega. Ilustrações de Carybé. 